\title{
Suggestopedia Method Effect On Reading Descriptive Text at A Senior High School
}

\author{
Suyadi \\ Fakultas Keguruan dan Ilmu Pendidikan, Universitas Batanghari Jambi \\ Jl. Slamet Ryadi, broni-Jambi, 36122 \\ Correspondence email: suyadi@unbari.ac.id, suyadi@yahoo.com
}

\begin{abstract}
Suggestopedia is a teaching method focuses on the teacher-learner relationship while teaching and learning process is going on in the classroom that might be used to encourage the students especially for reading a descriptive text. This study was to explore the senior high school students' ability on reading descriptive text by using a quantitative method with a quasiexperimental approach. Sample was taken randomly, with 60 students were devided into two groups, 30 students were taken as control class while another 30 students as experimental class. By using a reading text as the instrument of the research, the researcher found that suggestopedia method was proven to be effective with the average pre-test control class was 38,6 and posttest control class was 53,3. The average pre-test in the experimental class was 46 and post-test experimental class was 90,8 . The value of $t$-test higher than the value of t-table was $(20,41>2,001)$ which means that suggestopedia method makes learning process more interesting and more effective for senior high school students.
\end{abstract}

\section{Keywords: Suggestopedia; Reading Comprehension; Descriptive Text; Method}

\begin{abstract}
Abstrak. Suggestopedia merupaka sebuath metode pengajaran yang menitikberatkan pada hubungan antara guru dan pembelajar ketika proses belajar-mengajar berlangsung di dalam ruang kelas yang dapat digunakan untuk memotivasi siswa dalam belajar, terutama ketika belajar Bahasa Inggris dengan topic Reading Descriptive text. Penelitian ini bertujuan untuk mengeksploraasi kemampuan siswa Sekolah Menengah Atas (SMA) dalam membaca teks deskriptif berbahasa Inggris dengan menggunakan metode kuantitatif melalui pendekatan quasi-experimental (eksperiment tak penuh). Dengan pengambilan sampel secara acak, peneliti mendapati 60 orang siswa yang dibagi menjadi dua kelompok yang masing-masing kelompok terdiri dari 30 orang dengan rincian 30 kelompok control, dan 30 orang lainnya kelompok eksperimen. Dengan menggunakan teks bacaan sebagai instrumen penelitiannya, peneliti menemukan bahwa metode sugestopedia terbukti efektif dengan rata-rata pre-test kelas kontrol adalah 38,6 dan kelas kontrol post-test adalah 53,3. Rata-rata pre-test di kelas eksperimen adalah 46 dan post-test kelas eksperimen adalah 90,8 . Nilai t-test lebih tinggi dari nilai t-tabel $(20,41>2,001)$ yang berarti metode sugestopedia membuat proses pembelajaran lebih menarik dan efektif bagi siswa SMA.
\end{abstract}

Kata Kunci: Suggestopedia; Reading Comprehension; Descriptive Text; Method

\section{INTRODUCTION}

One of the English language skill that need to be mastered by the students is reading, which may lead learners of English as a Foreign Language enriching their knowledge. Having a good understanding of reading English text may trigger learners to get better information especially broadening vocabulary, strengthening the knowledge of grammar, comprehending text, and knowing kinds of text by reading intensively and continuously.

Wolly (2011: p.15) stated that reading comprehension is the process of making meaning from the text in order to understand of what is described in the text. To comprehend the text, the students must be able to construct the meaning internally from interacting with the material that is read. As a result, they are expected not only be able to read the text but also to master reading with comprehension. Therefore, reading is not as easy as what people think because it is not only read a sentence and say it out to others but also we have to understand the content of the reading text and its purpose. Some students in learning English get some difficulties in comprehend the text, more specifically comnprehending descriptive text for the students of Senior High School in Jambi City

Descriptive text is a text which describes what a person, place, animal or a thing is like and the generic structures of descriptive text are identification and description.Descriptive text as one of kinds of text ussually practiced by reading, but teachers are seldom providing to use method, method can help learning process in the classroom, and students usually more enjoy in the laerning by using method. In this research, the researcher is interested in using suggestopedia in teaching reading as a method that can be used to achieve the learning objective.Related to the method suggestopedia, Harmer (2001:89), Suggestopedia is a method that have a physical surroundings and the classroom atmosphere. The students can be relaxed, having fun, and comfortable in teaching learning process. Suggestopedia is a teaching method which was developed by a Bulgarian doctor and psychotherapist, Georgi Lozanov. It is involvet physical activities, educational, artistic and musical, and students must be 
comfortably relaxed in learning process by soft music or classical as the background. The teacher brings the material and motivate for students. To make the classroom comfortable in reading process without students difficult to get ideas from the text.

\section{Literature Review}

Reading comprehension is a complex skill that requires an active interaction between the reader and elements of the text. The reader is an active participant with a text and also the reader makes sense of how ideas based on the text related to one another by interactions between what the reader gains from the text and what the reader already knows. Then, a comprehension of reading a text is a must thing to be understood by all the readers, as it is crucial to the study of reading.

To comprehend this understanding, Cain (2004) defined a reading comprehensing as the process of making meaning by coordinating a number of complex processes that involve language, word reading, word knowledge, and fluency. In line with Cain, Durkin (1993) defined that a reading comprehension is a complex interaction among automatic and strategic cofnitive processes that enable the reader to create a mental representation of the text. While, Torgesen stated in Klinger (2007: p.8) stated that a reading comprehension is thus a cofnitive, motivational, and affective activity.

The activity of reading an English text has a specific challenge faced by the learner of English as a Foreign Language, in more specifically the student of senior high school. Thus, in order to get a better understanding of reading an English text the experts propose some level reading comprehension, stated as follows:

\section{Levels of Reading Comprehension}

Burns (1984: p.177) proposed four levels of reading comprehension as follows:

(1) Literal Comprehension: it involves acquiring information that is directly stated, the basic of literal comprehension is recognizing stated the main idea, detailed caused effect and sequence. It is also prerequisite for higher-level understanding. The important in this level is understanding of vocabulary, sentence meaning, and paragraph meaning.

(2) InterpretativeComprehension: it involves reading between the lines or making inferences. It is the process of deriving ideas that are implied rather than directly stated which involve the skills of interpretative as follows: 1) Inferring main ideas of passages in which the main ideas are not directly stated, 2) Inferring cause-effect relationships when they are not directly stated, 3) Inferring referents of pronouns, 4) Inferring referent of adverbs, 5) Inferring omitted words, 6) Detecting mood, 7)
Detecting the author's purpose in writing, and 8) Drawing conclusion.

(3) Critical Comprehension: is an evaluating written material comparing ideas discovered in teaching material by knowing the standards and drawing conclusion of its accuracy, appropriatness, and timeliness. The critical reader must be an active reader, questioning, searching for facts, and suspending judgment until he or she has considered all of the material. Critical reading depends upon literal comprehension, and grasping implied ideas is especially important.

(4) Creative Comprehension: it involves going beyond the material presented by the author, and the reader need to think as they read just as a critical reader does, and of course, they need imaginations to understand the text. Through creative reading the reader creates something new idea, the solution to a problem, a new way of looking at something from the ideas gleaned from the text.

\section{Types of Reading Comprehension}

Wagner (1960:207) in Suyadi (2020: p. 12) states there are varieties of sfecific comprehension abilities, the abilities grow out of the purposes for which material is read. The important specific comprehension abilities are:

1. Reading for factual information: reading for a detailed information and as well a fundamental concepts of the scenic points. Reading for specific information is as a general, somewhat isolated facts, and isolated concepts.

2. Reading to organize: an organization of information is more usable and more likely to retain in order to use reading efficiently as an aid in learning.

3. Reading to evaluate: is a type of comprehension in which the reader appraise the worth whildness, the relevancy, or the accuracy of one or more passages.

4. Reading to interpret: involves a high order reasoning with the material and includes those reading comprehension abilities of the reader use to restructure the information presented to understand the implication.

5. Reading for appreciation: is impressionistic reading which carries the reader somewhat beyond the stated elements of the discourse.

\section{Suggestopedia Method}

Suggestopedia is an old method but still has good impact on teaching and learning process. It was developed by Bulgarian doctor psychotherapist and educator, Georgi Lazanov (1982: p.32) said that suggestopedia help learners to eliminate pshychological barriers in learning. The learning environment is relaxed and subdued, with low lighting and soft music in the background where the students just relax and listen to them being read and later playfully practice the language during an "activation" phase. From the idea of 
suggestopedia, the classroom environment will be set playfully and enjoyable during the learning process. Harmer (2001) put more intension on learner's desire in learning and believes that music can stimulate learner's desire engage in learning, since it addresses emotions and meanwhile allows the brain to analyze its ffect. A piece of music can change the classroom atmosphere and initiate a new activity, while establishing a connection between relaxation and learning (Harmer, 2001).

Furthermore Venkanna \& Glorry, (2015: p.130) added that the effect of physical surrounding and pleasant atmosphere of the classroom can make the students relaxed, confident and comfortable in reading the text because they do not feel under pressure to learn in the classroom. The purpose of this method is to make the students relax and enjoy during the learning process. Music in the learning process background helps to make students focus and concentrate to the material.

\section{Characteristic of Suggestopedia}

Richards and Rodgers suggested four characteristics of suggestopedia (1999:p.142) as follows:

1. Decoration: it involves teacher's creativity to decorate classroom with different situation while teaching and learning process is going on to attract the students' attention during the process, by putting the wall-picture or poster related to the teaching materials.

2. Furniture: it is used to help students having feeling comfortable like arranging table, chair, lamp, whiteboard, and many other interesting things in the classroom.

3. Arrangement of the classroom: the students can arrange their chair of the classroom to make them not easy to get bored, and more interesting.

4. The use of music: it can help students to relax by listening some Baroque music as a therapy in suggestopedia method. Classical music aids in the creation of a positive emotional response to the program of memorization in learning process, and bring students into the optimum mental state for effortless acquisition of material.

\section{Technique of Suggestopedia}

Diane Larsen-Freeman (2000: p.113) proposed technique and classroom set-up of suggestopedia as follows:

1. Classroom set-up: to create the class cheerfulness an positive mindset.

2. Peripheral learning: to provide students with grammatical information from decoration, and exposed themselves in the process of teaching and learning in the classroom.

3. Positive suggestion: The teacher has responsibility to arrange the suggestive factors in learning situation with tell a positive suggestion like tells students are going successful. It is make them get believe in her/his self and relax without pressure in the learning process.

4. Choose a new identity: students choose a target language name and occupation to have an opportunity to develop a whole biography about their fictional selves.

5. Role play: asked students to pretend to be other character to create their own lines in target language.

6. First concert (active concert): teacher gives a dialogue in order to create students; attention on grammatical, words, structure of the text by reading aloud with diverse intonation.

7. Second concert (passive concert): In particular, fulfills Williams in passive concert the students are creating their fantasy with closing their eyes: a comfortable, quite place, and instruction of teacher with a pleasing voice by slow-paced presentation.It means that the students have relaxed but do not sleeping to create their imagination about the story that teacher's read.

8. Primary activation: The students playfully reread the target language dialogue out load, as individuals or in group. They can practice in front of the class with many expression based on dialogue like angrily, sadly, cheerfully etc.

9. Creative adaptation: The students engage various activities designed to help them learn the new material, to review and consolidate the leaning. The activities include singing, dancing, dramatization, and games which students just only focus in the communicative intent do not focus on the form of the linguistic message.

\section{Suggestopedi in Teaching Reading Comprehension}

The use of suggestopedia in teaching and learning reading comprehension is much needed in correlation to encourage students' mental potential to learn while having relaxed situation of learning in the classroom. The students can get a better understanding in learning the lesson easily. Using music while teaching and learning process can make the students easi to gain the knowledge.

The effect of suggestopedia method in teaching reading comprehension are as follows:

1. Teacher should arrange the classroom such as the students' chair, desk, the classroom decoration and the condition of the classroom.

2. Before come to the class, all tools that will used by the teacher should be prepared.

3. After the classroom has been arranged, the teacher should make sure the students that they are ready to study.

4. Before going to the material, the music was played by the teacher. Also, teacher asked students to relax, calm and enjoy the music. 
5. Teacher give the material with some activities in suggestopedia method such as role play, games, etc, related to the reading comprehension.

6. While doing role play or games, teacher may play the music with the lower sound.

\section{Descriptive Text}

A descriptive text is a kind of text which has purpose to describe a particular person, thing or place in details. Like another genre, through this text the students learn about social function, generic structure and grammatical features. Gerot and Wignell (1995: p.208) define descriptive text is kind of text whichis aimed to describe a particular person, place or things.It can be conclude that descriptive text is a text for describe person, place ora thing by visual experience. It is used to create a visual image of people,place, even of time days or season. It may also be used to describe the outwards appearance people. It may tells about their traits of character and personality. Furthermore Mark \&Anderson (2003) say that descriptive text is a text that states a factual description specifically to describe a particular place or thing.

Endang Fauziati et al (2013: p. 235) stated the language features of descriptive text as follows: 1) Certain nouns, such as teacher, house, my cat, bridge, etc. 2) Simple Present Tense, 3) Detailed noun phrases to give information about a subject, such as It was a large open rowboat, a sweet young lady, the deaf person, etc, 4) Various adjectives which are describing, numbering, classifying such as two strong legs, sharp white fangs, her curly hair, etc. 5) Relating verbs to give information about a subject, such as My mum is really cool; It has very thick fur, the rest remains at home, etc. 6) Thinking verbs and feeling verbs to reveal the writer's view, such as The police believe the suspect is armed; I think it is a clever animal, etc. 7) Action verbs, such as Our new puppy bites our shoes; It eats soft food, etc. 8) Adverbs to give additional information about manner, such as fast, gradually, at thetree house, etc. 9) Figurative language, such simile, metafor, e.g. John is white as chalk, sat tight, etc.

Descriptive text describes characteristics of particular place, person, or thing, and showing the social function of the mentioned characteristics. The generic structure of descriptive text are identification which introduces objects or things including who, what, where, and when of the situation described, and description which describes of objects or things, including who, what, where, when in a very detail description.

\section{METHODOLOGY}

An experimental study aims to investigate if there is any treatment effect on the participants' behaviours, or their internal processes, or improvement on the scores study they follow in a certain classroom. Experimental study is entailed manouvering or artificially manipulating learning situations. A typical treatment effect is given to the control class to see the effect of using a research equipment, and in this research it is called suggestopedia method for descriptive text effect on the students' scores. Khotari (2004: p. 30) states that control group is the group which was exposed to usual condition while experimental group was a group which was exposed to special condition. In this research the researcher used one pre-test and post-test design included assignment. In the one group pre-test and posttest, a single group is measured or observed not only after being exposed to a treatment but also before. In pre-test and post-test group the observation do two times, before giving treatment called pre-test and after giving treatment called post test.

In education research, independent variables are generally manipulated in three different ways (Johnson \& Christensen, 2010: p. 286). The first is "by a presence or absence technique", through which an experimental group receives some intervention, whereas the control group does not (see the review on Brett, Rothlein \& Hurley, 1996). The second way is to manipulate the amount of administration of a certain intervention (Hulstijn, 1997). For example, one might presume that providing feedback to learners' writing twice is more effective than doing so once. Then one could manipulate the amount of feedback given to students by having one group which receives feedback twice, another group being given one feedback session, and the third group being deprived of any feedback. A third way is to manipulate the independent variable by varying the type of instructional techniques used. For example, Ramachandran and Rahim (2004) compared the relative effects of providing meanings of target English lexical items in the participants' first language (L1) and providing meanings of these items in English on English learners' vocabulary acquisition. English and L1 input of vocabulary thus represented two different types of teaching techniques in this study. It is noteworthy that several combinations of the above are implemented in ETL research (for example, three treatment groups respectively receiving different teaching innovations in addition to a control group with the lack thereof).

\section{Sample}

Bordens (2008: p.163) states that a sample is a small subgroup chosen from the larger population. So, the sample was the students from the population who were chosen to participate in this study. In this research researcher used random sampling which was selected the participants by giving a chance of procedure to have an equal probably of being participants. There were 30 students of Science 2 Classroom taken as Experimental Group, and 30 students of Science 4 Classroom taken as Control Group

The sampling procedure was taken 5 classes of population which gradually taken two classes as the 
sample of the research. First, researcher prepared paper, pen, and glass then researcher cut into 5 pieces of paper, next write all the class on 5 pieces of paper, roll it and out into glass, after that removed 2 rolls from the glass, so 2 rolls of paper are class X MIPA 2 (Science Class 2) and X MIPA 4 (Science Class 4) that the researcher made a sample in this research.

\section{Instruments of the Research}

The researcher collected the data by using a reading test. Reading comprehension test

The students were given a descriptive text in the form of multiple choice. The aims of this exercise were to find main idea, finding specific information, Interpreting problems/inferences, understanding vocabulary, and making a generalization references. The test was devided into two, they were pre-test and posttest. The researcher gave the same test for experimental and control group. The researcher gave items tested to 35 subjects to measure validity and reliability in pre-test and post-test.

Table 1. Specification of Content Reading Comprehension Test

\begin{tabular}{llll}
\hline No & Indicator of reading comprehension & Items number & Percentage \\
\hline 1 & Identifying main idea & $5,10,11,16,25,30,35$ & $20 \%$ \\
2 & Finding specific information & $3,9,14,18,24,27,34$ & $20 \%$ \\
3 & Interpreting problems/inferences & $4,8,15,17,21,26,33$ & $20 \%$ \\
4 & Understanding vocabulary & $2,6,12,19,23,28,32$ & $20 \%$ \\
5 & Making a generalization references & $1,7,13,20,22.29,31$ & $20 \%$ \\
& Total & 35 items & $100 \%$ \\
\hline
\end{tabular}

Source:Anindya Sekarini (2017:28)

\section{Validity of the Test}

Validity of the test is the extent to which a test measures what it is intended to measure. According to Field (2005) validity basically means measure what is intended to be measure. In this research the researcher used content validity. Content validity was done to see the content of instrument in learning material given by the teacher. it had been counted index difficulty and index discrimination. (The result of validity test can be seen on appendix 2 page 75 )

\section{Index Difficulty}

Difficult index is the ability of the test to filter the total number of participant who answers correctly. The categories of $0,00-1,0$ refered to difficulty index and it indicated the level of test difficulty. (The complete result of index difficulty can be seen on appendix 3page 76)

The difficult index formula as follows:

$P=\frac{\mathrm{B}}{\mathrm{JS}}$

Where:

$\mathrm{P}=$ Items difficulties.

$\mathrm{B}=$ Sum of the students who answered correctly.

$\mathrm{JS}=$ Sum of all students who followed the test.

The classification of item difficulty is as follow:
P $0.00-0.30$ difficult

P $0.31-0.70$ moderate

P $0.71-1.00$ easy

\section{Index Discrimination}

Index discrimination is the test ability to separate the students who have high ability students and low ability. (The complete result of index discrimination can be seen on appendix 4 page 77).

The index discrimination formula:

$\mathrm{D}=\frac{\mathrm{BA}}{\mathrm{JA}}-\frac{\mathrm{BB}}{\mathrm{JB}}=\mathrm{P}_{\mathrm{A}}-\mathrm{P}_{\mathrm{B}}$

Where:

$\mathrm{D}$ : Discrimination index

$\mathrm{J}:$ Number of participant

JA : Number of top group participants

JB : Number of bottom group participants

BA : Number of the top group participants who answer correctly

BB : Number of the bottom group participants who answer correctly

PA : Propotion of top group participants who answer correctly

PB : Propotion of bottom group participants who answer correctly

Discrimination index categories:

D : 0,00-0,20 : Poor

D : $0,20-0,40:$ Satisfactory

D : $0,40-0,70$ : Good

D : 0,70-1,00 : Excellent

$\mathrm{D}:$ Negative, all is poor.

\section{Reliability of theTest}

Reliability is the degree to which an assessment tool produces stable and consisten result. Similarly, Hughes adds that to be valid a test must provide consistently accurate measurement. It must therefore be reliable. It means that reliability was necessary in the research to assess the good instrument or not.

In order to get the reliability of the test, the researcher used product moment formula to measure the reliability of instrument.

$$
r_{x y}=\frac{N \sum x y-\left(\sum x\right)\left(\sum y\right)}{\sqrt{\left\{N \sum_{x}^{2}-\left(\sum x\right)^{2}\right\}\left\{N \sum_{y}^{2}-\left(\sum y\right)^{2}\right\}}}
$$

Where:

$\mathrm{r}_{\mathrm{xy}}$ : Coefficient correlation between $\mathrm{x}$ and $\mathrm{y}$ variables

$\mathrm{N}$ :Numbers of students

$\sum \mathrm{x}:$ Sum of $\mathrm{x}$

$\sum y:$ Sum of $y$

$\sum \mathrm{x} 2:$ Square of $\mathrm{x}$

$\sum \mathrm{y} 2:$ Square of $\mathrm{y}$

$\sum_{\mathrm{xy}}$ : Total scores of cross product $\mathrm{x}$ and $\mathrm{y}$ 
The test result of this research instrument is interpreted using the following guidance:

Table 2. Interpretation Guide

\begin{tabular}{ccc}
\hline No & Level of reliability & Description \\
\hline 1 & $0,800-1,000$ & Very high \\
2 & $0,600-0,799$ & High \\
3 & $0,400-0,599$ & Fair \\
4 & $0,200-0,399$ & Low \\
5 & $0,000-0,199$ & Very low \\
\hline
\end{tabular}

(Arikunto, 2013: p. 319)

After the instrument reliability figure is known, then the number is interpreted with the level of reliability of the correlation coefficient. The instrument is said to be reliable if it has a cronbach's alpha coefficient of more than or equal to 0,700 then the instrument is said to be reliable.

Table 3. Result of Reliable Test

\begin{tabular}{cccc}
\hline Variable & Cronbach Alpha & Requirement & Description \\
\hline Suggestopedia Method $(\mathrm{X})$ & 0,876 & $>0,7$ & Reliable \\
\hline
\end{tabular}

Based on reliable test result above the variable suggestopedia method $\mathrm{X} 0,876>0,7$ is reliable.

\section{Technique of Data Collection}

This research needed the data to support the investigation and researcher used quantitative research to collect data, so collected was one of the most important step when doing research. In this research, Cresswell (2009: p. 4) states that quantitative research is a mean for testing objective theories by examining the relationship among variables, in turn, can be measured typically on instruments, so that numbered data can be analyzed using statistical procedures. The final written report has a set structure consisting of introduction (literature and theory), methods (result), and discussion.

1. Pre-test

The pre-test conducted both of the groups, experimental and control group in order to know students'on reading comprehension in descriptive text before treatment given.

2. Treatment

the next steps, the researcher giving treatment to the students. There are different treatment given to experimental class and control class. In experimental class, the researcher treat reading descriptive text using suggestopedia teaching method stages, and to control class the researcher treat them without suggestopedia teaching method. Both of the treatment the researcher focus to teach about describing place, consist of describing place consists of describing a room, a city, buildings, or toursm place.

3. Post-test

The last, the test will giving to the students after the treatment. The type of the pre-test is text, and the result effect of the treatment will be seen from the post-test. Same with the the researcher using reading test to find out the improvement student's ability in readinf descriptive text, the researcher ask the students to read a descriptive text but just focus on describing place.

\section{Technique of Data Analysis}

The data used analyze bystudents score, normality test, and the t-test.

\section{Students Score}

It is used to find the students individual scores in the test given. Most commonly percentage of scores in a specified distribution that fall below the point at which given scores lies. Sometimes the individual scores is defined to include score the fall at the points, sometimes the individual score is defined to include half of score at the point.

The formula is a follows:

$x=\frac{\mathrm{R}}{\mathrm{N} 1} \times 100$

Where:

$\mathrm{X}$ : Score of individual result

$\mathrm{R}$ : Number of correct answer

Table 4. Classification of Student's Scores

\begin{tabular}{cc}
\hline Test Score & Classification \\
\hline $91-100$ & Excellent \\
$81-90$ & Very good \\
$71-80$ & Good \\
$61-70$ & Fair \\
$51-60$ & Poor \\
$0-50$ & Very poor \\
\hline
\end{tabular}

(adapted from Subana, Rahadi, and Sudrajat: 2015)

- To look for the mean score, the researcher uses formula is presented as follows:

$M=\frac{\sum \mathrm{X}}{\mathrm{N}}$

Explanations :

$\mathrm{M}=$ Mean score

$\sum \mathrm{X}=$ The total score

$\mathrm{N}=$ The total number of sample

- Pre-test and post-test calculation by the following formula :

$P=\frac{\mathrm{f}}{\mathrm{n}} x 100$

Explanations :

$\mathrm{P}=$ The percentage of score

$\mathrm{F}=$ The number of false score

$\mathrm{N}=$ The number of students

- T-test

To collected data the research used pre-test, treatment, and post-test. After collecting the data by 
used test, it can to analyzed the data using t-test. Ttest which formulated to know the significant differences between pre-test and post-test

The formula T-test is taken from Arikunto (2006:349) as followed :

$t=\frac{M_{y-} M_{x}}{\sqrt{\frac{\left[\sum X^{2}+\sum Y^{2}\right]}{N x+N y-2}}}$

Explanations :

$\mathrm{t}=\mathrm{T}$-test Value

$M x=($ differences $)$, between pre-test and post-test score

My $=$ (differences), between pre-test and post-test score

$\sum x^{2}=$ quadrate of deviation

$\mathrm{N}=$ The number of sample

d.b $=\mathrm{N}-1$

\section{FINDINGS}

This chapter presents data collection of experimental class and control class on one of State Senior High School in Jambi City where pre-test and post-test given. The researcher conducted this research for 3 weeks to prove the effect of using suggestopedia method on reading comprehension in descriptive text. The researcher taken two class as sample, the sample of this research get of simple random sampling. The result of the simple random sampling is there are X MIPA 2 and X MIPA 4 one class consist (30 students) and other class consist (30 students) they are equal (60 students). The researcher did this research start from on February 15, 2021 until March 15,2021. The researcher present the data from the test, test in this research are pre-test, treatment, and the last post-test.

Pre-test was conducted to both control class and experimental class. It was conducted to know the initial ability of the students especially in their comprehension skills of descriptive text. The score between two class was expected relatively similar to each other so that it could be assumed that the improvement of their score was treatment. Treatments were conducted after the pretest was administered. It was given only to the experimental class in which during the teaching and learning process the method used was the suggestopedia. It does not mean that the control class did not get any treatments, but during the taching and learning process the control class was treated by conventional method.

Post-test was conducted to know the improvement of the student's score. It can be said that there was the change between the score in pre-test and post-test. Besides, it was to know that whether or not there was a significant difference between control and experimental class.
Table 5. The Activity of Pre-test, Treatments, and post-test

\begin{tabular}{|c|c|c|}
\hline \multirow[t]{2}{*}{ Day/Date } & \multicolumn{2}{|l|}{ Activity } \\
\hline & Experimental Class & Control Class \\
\hline Thursday $/ 15$ - Feb -21 & Pre-test & Pre-test \\
\hline Thursday $/ 22-\mathrm{Feb}-21$ & $\begin{array}{l}\text { Treatment 1: Introduction of } \\
\text { Suggestopedia Teaching Method, } \\
\text { Class preparation (classroom set- } \\
\text { up), positive suggestion, practice } \\
\text { (story telling about Kuta Beach). }\end{array}$ & $\begin{array}{l}\text { Modeling of reading text, } \\
\text { asking and answering, } \\
\text { reading exercise. (Kuta } \\
\text { Beach). }\end{array}$ \\
\hline Thursday/8 - March - 21 & $\begin{array}{l}\text { Treatment 2: Class preparation } \\
\text { (classroom set-up), positive } \\
\text { suggestion, practice ( role play and } \\
\text { story telling about Pink Beach.) }\end{array}$ & $\begin{array}{l}\text { Modeling of reading text, } \\
\text { asking and answering, } \\
\text { reading exercise. (Pink } \\
\text { Beach). }\end{array}$ \\
\hline Wednesday $/ 15$-March - 21 & $\begin{array}{l}\text { Treatment 3: Classroom set-up, } \\
\text { Active Concert, Passive Concert, } \\
\text { practice (story telling about } \\
\text { Borobudur Temple and games) }\end{array}$ & $\begin{array}{l}\text { Modeling of reading text, } \\
\text { asking and answering, } \\
\text { reading exercise. } \\
\text { (Borobudur Temple). }\end{array}$ \\
\hline Thursday/12 - March & Post-test & Post-test \\
\hline
\end{tabular}

\section{Descriptive analysis}

In this section, the researcher explain the mean, percentages and $\mathrm{t}$ - test scores of the test based on the results of the test before and after the interventation in both experimental class. The result of pre-test in control class and experimental class as a follows:

Table 6. The Result of Pre-Test Control Class (MIPA 4)

\begin{tabular}{ccc}
\hline No & Name of Students & Score \\
\hline 1 & Student1 & 40 \\
2 & Student2 & 45 \\
3 & Student3 & 30 \\
4 & Student4 & 35 \\
5 & Student5 & 45 \\
6 & Student6 & 50 \\
7 & Student7 & 30 \\
8 & Student8 & 35 \\
9 & Student9 & 45 \\
10 & Student10 & 35 \\
11 & Student11 & 30 \\
12 & Student12 & 30 \\
13 & Student13 & 35 \\
14 & Student14 & 40 \\
15 & Student15 & 45 \\
16 & Student16 & 45 \\
17 & Student17 & 50 \\
18 & Student18 & 45 \\
19 & Student19 & 35 \\
20 & Student20 & 35 \\
21 & Student21 & 30 \\
22 & Student22 & 40 \\
23 & Student23 & 30 \\
24 & Student24 & 45 \\
25 & Student25 & 40 \\
26 & Student26 & 45 \\
27 & Student27 & 45 \\
28 & Student28 & 30 \\
29 & Student29 & 40 \\
30 & Student30 & 35 \\
& Total & $\mathbf{1 1 6 0}$ \\
& Average & $\mathbf{3 8 . 6}$ \\
\hline & & \\
& & C
\end{tabular}

Based on the table above, the number of students in control class was 30 students. Students who got the highest score of 50 were 2 people, 9 students got a score of 45, 5 students got a score of 40, 7 students got a score of 35 , and the lowest with a score of 30 were 7 students. With the total overall scores were 1.160. The average of pre-test in control class was 38.6. The researcher was given a treatment after pre-test. 
Table 7. The Result of Pre-Test Experimental Class (MIPA 2)

\begin{tabular}{ccc}
\hline No & Name of Students & Score \\
\hline 1 & Studen1 & 35 \\
2 & Student2 & 30 \\
3 & Studen2 & 40 \\
4 & Student3 & 45 \\
5 & Studen3 & 50 \\
6 & Student4 & 45 \\
7 & Studen4 & 45 \\
8 & Student5 & 30 \\
9 & Studen5 & 35 \\
10 & Student6 & 50 \\
11 & Studen6 & 45 \\
12 & Student7 & 50 \\
13 & Studen7 & 55 \\
14 & Student8 & 65 \\
15 & Studen8 & 65 \\
16 & Student9 & 45 \\
17 & Studen9 & 50 \\
18 & Student10 & 55 \\
19 & Studen10 & 50 \\
20 & Student11 & 40 \\
21 & Studen11 & 45 \\
22 & Student12 & 40 \\
23 & Studen12 & 35 \\
24 & Student13 & 45 \\
25 & Studen13 & 50 \\
26 & Student14 & 50 \\
27 & Studen14 & 45 \\
28 & Student15 & 40 \\
29 & Studen15 & 45 \\
30 & Student16 & 60 \\
& Total & $\mathbf{1 3 8 0}$ \\
& Average & $\mathbf{4 6}$ \\
\hline & &
\end{tabular}

Based on the table above, the number of students in experimental class was 30 students. Students who got the highest score of 65 were 2 people, 1 students got a score of 60, 2 students got a score of 55, 7 students got a scoreof 50, 9 students got a score of 45, 4 students got a score of 40, 3 students got a score of 35, and the lowest with a score of 30 were 2 students. With the total overall score was 1.380. The averageof pre-test in experimental class was 46. The researcher was given a treatment after pre-test. After giving the treatment researcher giving post-test. The result of post-testt in control class and experimental class as a follows:

Table 8. The Result of Post-Test Control Class (MIPA 4)

\begin{tabular}{ccc}
\hline No & Name of Students & Score \\
\hline 1 & Student1 & 60 \\
2 & Student2 & 55 \\
3 & Student3 & 50 \\
4 & Student4 & 45 \\
5 & Student5 & 55 \\
6 & Student6 & 65 \\
7 & Student7 & 45 \\
8 & Student8 & 45 \\
9 & Student9 & 50 \\
10 & Student10 & 55 \\
11 & Student11 & 35 \\
12 & Student12 & 40 \\
13 & Student13 & 45 \\
14 & Student14 & 50 \\
15 & Student15 & 55 \\
16 & Student16 & 65 \\
17 & Student17 & 65 \\
18 & Student18 & 60 \\
19 & Student19 & 60 \\
20 & Student20 & 50 \\
21 & Student21 & 55 \\
22 & Student22 & 65 \\
23 & Student23 & 60 \\
24 & Student24 & 60 \\
25 & Student25 & 55 \\
26 & Student26 & 50 \\
27 & Student27 & 55 \\
28 & Student28 & 45 \\
29 & Student29 & 55 \\
30 & Student30 & 50 \\
& Total & $\mathbf{1 6 0 0}$ \\
& Average & $\mathbf{5 3 . 3}$ \\
\hline & &
\end{tabular}

Based on the table above, the number of students in control class was 30 students. Students who got the highest score of 65 were 4 people, 5 students got a score of 60,8 students get a score of 55,6 students get a score of 50, 5 students got a score of 45,1 students got a score of 40, and the lowest with a score of 35 were 1 students. With the total overall score was 1.600. The average of post-test in control class was 53.3.

Table 9. The Result of Post-Test Experimental Class (MIPA 2)

\begin{tabular}{ccc}
\hline No & Name of Students & Score \\
\hline 1 & Student1 & 85 \\
2 & Student2 & 75 \\
3 & Student3 & 85 \\
4 & Student4 & 90 \\
5 & Student5 & 90 \\
6 & Student6 & 80 \\
7 & Student7 & 90 \\
8 & Student8 & 80 \\
9 & Student9 & 85 \\
10 & Student10 & 90 \\
11 & Student11 & 90 \\
12 & Student12 & 95 \\
13 & Student13 & 95 \\
14 & Student14 & 100 \\
15 & Student15 & 100 \\
16 & Student16 & 90 \\
17 & Student17 & 95 \\
18 & Student18 & 95 \\
19 & Student19 & 90 \\
20 & Student20 & 85 \\
21 & Student21 & 90 \\
22 & Student22 & 95 \\
23 & Student23 & 80 \\
24 & Student24 & 95 \\
25 & Student25 & 95 \\
26 & Student26 & 100 \\
27 & Student27 & 95 \\
28 & Student28 & 95 \\
29 & Student29 & 95 \\
30 & Student30 & 100 \\
& Total & $\mathbf{2 7 2 5}$ \\
& Average & $\mathbf{9 0 . 8}$ \\
\hline & & \\
& &
\end{tabular}

Based on the table above, the researcher concluded the post test in experimental class, the number of students in experimental class was 30 students. Students who got the highest score of 100 were 4 people, 10 students got a score of 95,8 students got a score of 90,4 students got a score of 85,3 students got a score of 80 , and the lowest with a score of 75 were 2 students. With the total overall score was 2.725. The average of post-test in experimental class was 90.8 .

\section{Statistical analysis \\ Result of pre-test and post-test in experimental class}

The result of pre-test before the interventation, shows that all of students were categoriezed very poor. The lowest score and the highest score in some score interval 0-50.

Table 10. The Mean of Pre-Test in Experimental Class

\begin{tabular}{cccc}
\hline No & Score $(\mathbf{M x})$ & Frequency (My) & Total (Mx My) \\
\hline 1 & 30 & 2 & 60 \\
2 & 35 & 3 & 105 \\
3 & 40 & 4 & 160 \\
4 & 45 & 9 & 405 \\
5 & 50 & 7 & 350 \\
6 & 55 & 2 & 110 \\
7 & 60 & 1 & 60 \\
8 & 65 & 2 & 130 \\
Total & $\Gamma \mathbf{M x}=\mathbf{3 8 0}$ & $\Gamma \mathbf{M y}=\mathbf{3 0}$ & $\Gamma(\mathbf{M x} \mathbf{M y})=\mathbf{1 . 3 8 0}$ \\
\hline
\end{tabular}


$M=\frac{\sum \mathrm{x}}{\mathrm{N}}$

$M=\frac{1.380}{30}$

$M=46$

Based on the calculated, it can be concluded that the mean value of pre-test in experimental class was 46. The table of value of post-test in experimental class can be seen in table below:

Table 11. The Mean of Post-Test in Experimental Class

\begin{tabular}{cccc}
\hline No & Score $(\mathbf{M x})$ & Frequency (My) & Total (Mx My) \\
\hline 1 & 75 & 1 & 75 \\
2 & 80 & 3 & 240 \\
3 & 85 & 4 & 340 \\
4 & 90 & 8 & 720 \\
5 & 95 & 10 & 950 \\
6 & 100 & 4 & 400 \\
Total & $\Gamma \mathbf{M x}=\mathbf{5 2 5}$ & $\Gamma \mathbf{M y}=\mathbf{3 0}$ & $\Gamma(\mathbf{M x} \mathbf{M y})=\mathbf{2 . 7 2 5}$ \\
\hline
\end{tabular}

$M=\frac{\sum x}{\mathrm{~N}}$

$M=\frac{2.725}{30}$

$M=90,8$

Based on calculated, it can be concluded that the mean value of post-test in experimental class was 90,8.

\section{Result of pre-test and post-test in control class}

The result of pre-test before the interventation, shows that all of students were categories very poor. The lowest score and the highest score in some score interval $0-50$. The table of value of pre-test in control class can be seen table 18 .

Table 12. The Mean of Pre-Test in Control Class

\begin{tabular}{cccc}
\hline No & Score (Mx) & Frequency (My) & Total (Mx My) \\
\hline 1 & 30 & 7 & 210 \\
2 & 35 & 7 & 245 \\
3 & 40 & 5 & 200 \\
4 & 45 & 9 & 405 \\
5 & 50 & 2 & 100 \\
Total & $\Gamma \mathbf{M x}=\mathbf{2 0 0}$ & $\Gamma \mathbf{M y}=\mathbf{3 0}$ & $\mathbf{( M x} \mathbf{M y})=\mathbf{1 . 1 6 0}$ \\
\hline
\end{tabular}

$M=\frac{\sum \mathrm{x}}{\mathrm{N}}$

$M=\frac{1.160}{30}$

$M=38,6$

Based on the calculated, it can be concluded that the mean value of pre-test in controlclass was 38,6.The table of value of post-test in controlclass can be seen table 19 .
Table 13. The Maen of Post-Test in Control Class

\begin{tabular}{cccc}
\hline No & Score $(\mathbf{M x})$ & Frequency $(\mathbf{M y})$ & Total $(\mathbf{M x}$ My) \\
\hline 1 & 35 & 1 & 35 \\
2 & 40 & 1 & 40 \\
3 & 45 & 5 & 225 \\
4 & 50 & 6 & 300 \\
5 & 55 & 8 & 440 \\
6 & 60 & 5 & 300 \\
7 & 65 & 4 & 260 \\
Total & $\Gamma \mathbf{M x}=\mathbf{3 5 0}$ & $\Gamma \mathbf{M y}=\mathbf{3 0}$ & \multicolumn{3}{c}{$\mathbf{M x} \mathbf{M y})=\mathbf{1 . 6 0 0}$} \\
\hline
\end{tabular}

$M=\frac{\sum \mathrm{x}}{\mathrm{N}}$

$M=\frac{1.600}{30}$

$M=53.3$

Based on calculated, it can be concluded that the mean value of post-test in control class was 53.3. The Score Distribution in The Experimental Class

Table 14. The score distribution in The Experimental Class

\begin{tabular}{cccccc}
\hline & & \multicolumn{2}{c}{ Pre-test } & \multicolumn{2}{c}{ Post-test } \\
\cline { 3 - 6 } Score interval & Category & Frequency & percentage & Frequency & percentage \\
\hline $91-100$ & Excellent & 0 & 0 & 14 & $47 \%$ \\
$81-90$ & Very Good & 0 & 0 & 12 & $40 \%$ \\
$71-80$ & Good & 0 & 0 & 4 & $13 \%$ \\
$61-70$ & Fair & 2 & $7 \%$ & 0 & 0 \\
$51-60$ & Poor & 3 & $10 \%$ & 0 & 0 \\
$0-50$ & Very Poor & 25 & $83 \%$ & 0 & 0 \\
\hline
\end{tabular}

From the table above, it can be seen that, in the pre-test no one students got excellent, no students got very good, no students got good,2 students got fair category, 3 students get poor category, 25 students get very poor category.

In post-test, it can be seen that is improvement in students score which mean improvement in students ability, 14 students get very excellent category, 12 students get very good category, 4 students get good category. In the post no one students got fair, poor and very poor category.

The Score Distribution in The control Class

Table 15. The score Distribution in The Control Class

\begin{tabular}{cccccc}
\hline \multirow{2}{*}{$\begin{array}{c}\text { Score } \\
\text { interval }\end{array}$} & Category & \multicolumn{2}{c}{ Pre-test } & \multicolumn{2}{c}{ Post-test } \\
\cline { 3 - 6 } & Frequency & percentage & Frequency & Percentage \\
\hline $91-100$ & Excellent & 0 & 0 & 0 & 0 \\
$81-90$ & Very Good & 0 & 0 & 0 & 0 \\
$71-80$ & Good & 0 & 0 & 0 & 0 \\
$61-70$ & Fair & 0 & 0 & 4 & $14 \%$ \\
$51-60$ & Poor & 0 & 0 & 13 & $43 \%$ \\
$0-50$ & Very Poor & 30 & $100 \%$ & 13 & $43 \%$ \\
\hline
\end{tabular}

From the table above, it can be seen in pre-test all students get very poor category, no onestudents get poor category, no one students get fair, good, very good, and excellent category. Meanwhile in post-test 4 students get fair category, 13 students get poor category, and 13 students get very poor category, no one students get good, no one students get very good, and excellent 
category, it is clearly proved students readingcomprehension that taught without suggestopediamethod not really improve.

\section{Data Analysis}

The table comparison between experimental class and control class.

Table 16. Different between control class and experimental class

\begin{tabular}{cccc}
\hline Variable & & Mean & The improvement \\
\hline Control group & Pre-test & 38.6 & \\
& Post-test & 53.3 & 14.7 \\
\hline Experimental group & Pre-test & 46 & \\
& Post-test & 90.8 & 44.8 \\
\hline
\end{tabular}

The result of control group and experimental group is different. The result of control group is 14,7 and experimental group is 44,8. Experimental group higher than control group. This result is significant. To know there is significant difference between experimental group score and control group score, $t$-test was higher than t-table. In order to see the significance between pretest and post-test before and after treatment of experimental group, the formula would be used analyze the data, the researcher was compared between the score of pre-test and post-test.

\section{The t-test result calculation}

$$
\begin{aligned}
\boldsymbol{t} & =\frac{\boldsymbol{M} \boldsymbol{x}-\boldsymbol{M} \boldsymbol{y}}{\sqrt{\left[\frac{\sum \boldsymbol{x}^{2}+\sum \boldsymbol{y}^{2}}{\boldsymbol{N x}+\boldsymbol{N y}-2}\right]\left[\frac{\mathbf{1}}{N \boldsymbol{x}}+\frac{\mathbf{1}}{\boldsymbol{n} \boldsymbol{y}}\right]}} \\
M x & =\frac{430}{30}=14.3 \\
\sum x^{2} & =\sum x^{2}-\frac{\sum X^{2}}{N} Y^{2} \\
& =7.250-\frac{430^{2}}{30} \\
& =7.250-6.163,3 \\
& =1.086,7 \\
M y & =\frac{1.335}{30}=44.5 \\
\sum x^{2} & =\sum Y^{2}-\frac{\sum X^{2}}{N} Y^{2} \\
& =60.225-\frac{1.335^{2}}{30} \\
& =60.225-59.407,5 \\
& =817,5 \\
\mathrm{t}= & \frac{14,3-44,5}{\sqrt{\left[\frac{1.086,7+817,5}{30+30-2}\right]\left[\frac{1}{30}+\frac{1}{30}\right]}} \\
& =\frac{+30,2}{\sqrt{\frac{1.904,2}{58}\left[\frac{2}{30}\right]}} \\
& =\frac{+30,2}{\sqrt{\frac{3.808}{1.740}}} \\
& =\frac{+30,2}{2,18850} \\
& =\frac{+30,2}{1,4793} \\
& =20.41 \\
&
\end{aligned}
$$

Based on the calculation of the statistical analysis, it is found that the value of t-test is 20,41 .

Finding t-table :

Number of variables $(\mathrm{k}) \quad=2$

Number of respondents (n) $\quad=58$

Taraf sig.

Degree of freedom (df)

$=5 \% \ldots 0,025$

$=(\mathrm{N} 1+\mathrm{N} 2)-2$

$=(30+30)-2$

$=58$

From the result of the distribution table, it was found that the t-table is 2,001. So, it can be concluded that $\mathrm{t}(58)=2.001$.

\section{Hypothesis testing}

From the calculation of t-test, the hypothesis can be tested as follow:

Null hypothesis (Ho) is accepted if the value of $\mathrm{t}$ test is the same or less than the value of $\mathrm{t}$-table (t-test=ttable or t-test $<\mathrm{t}$-table). In the fact, in this research, the null hypothesis is rejected because the value of t-test is higher than the value of t-table $(20,41>, 2,001)$. Alternative hypothesis (Ha) is accepted if the value of $\mathrm{t}$ test is higher than the value of t-table (t-test $>\mathrm{t}$-table). Thus, the alternative hypothesis is accepted, the value of $\mathrm{t}$-test is higher than the value of t-table $(20,41>2,001)$. Thus, it proved that there is the effect of using suggestopedia method on readingcomprehension in descriptive text at tenth grade of one senior high school in Jambi city.

\section{Discussion}

The discussion of this research is based on the research test, which was to know the effect of using suggestopedia method on reading comprehension in descriptive text at one of senior high school in Jambi city. At the beginning the researcher gave pre-test in experimental class and control class. In the control class,there is not a new treatment in a teaching learning process. They were given a usual treatment. They were taught comprehend descriptive text using convensional method as they have get, that is answer questions multiple choice on the text was given. By using conventional method in the teaching learning process, teacher had used a monotonous method that could not increase students comprehend in descriptive text. Students not enjoy in learning descriptive text because they have been feeling bored with long paragraph and don't relax when in reading process. Such treatment is carried out for 3 meetings using conventional method.

In the experimental class, there is a treatment in teaching learning process. The researcher used suggestopedia method.At the beginning the teacher make the students to relaxed and fun with the cheerful environment. Next, in first meeting the teacher storytelling the descriptive text about "Kuta Beach" text by follow the rhythm, games, and using instrumental 
music or soft music in the learning process. The researcher asks students, do they know this story and the students are very excited because they enjoy with storytelling. After that the researcher asks to the students the language feautures from the story and the students answer the question from teacher with confident. Such treatment is carried out for 3 meetings with different story. In the last activity, the researcher gave post-test in the control class and experimental class. The students had to answer questions multiple choice on the text was given by researcher. After the researcher got pre-test and post-test result, the researcher found the significant difference of their score in the experimental class and control class. It was influenced by the treatment, so the ability of the students improved. It can be seen from the result of their test.

Based on the post-test result, it was proven that the reading comprehension showed the differences in both experimental and controlled class. The mean of pretest score in experimental class is 46 . The mean of pretest score in controlled class is 38,6. Then, comparing with the mean of post test in experimental class is 90,83 and in controlled class is 53,3. In this research, source of data that was became as experimental class was class $\mathrm{X}$ MIPA 2 with 30 students, and control class was X MIPA 4 with 30 students. There were 30 students in experimental class and also 30 students in controlled class. From those results, it can be interpreted that posttest score of experimental and controlled class increased better than the pre-test. Although the mean of post-test score from both class increased, the experimental class has more improvement than controlled class. Thus, it can be concluded that suggestopedia method are in effective way to be used in improving students reading comprehension in descriptive text at the tenth grade students at one of senior high school in Jambi city.

\section{REFERENCES}

Anderson, M \& $\mathrm{K}$ Anderson. 2003. Text Types in English. New York: Macmillan.

Ary, D. (2010). Introduction to Research in Education. Canada. Wadswoth Cencage Lerning.

BurnsC.Paul, Roe D. Betty \& Ross P.Elinor. (1984). Teaching reading in today's elementary school $3 r d$. New York: Houghton Miffin.

Bordens, Kenneth. S. (2008). Research Design and Methods: a process approach/ Kenneth S. Bordens, Bruce B. Abbott-8th ed. Indiana University-Purdue University Fort Wayne,p.163

Cain, K. J., Oakhill, J., \& Bryant, P. (2004). Children's Reading Comprehension Ability: Concurrent Prediction by Working Memory, Verbal Ability, and Component Skills. Journal of Educational Psychology, 96(1), 31-42.

Creswell, John W. 2009. Research design. 3th ed. SAGE. University of Nebraska-Lincoln.
Creswell, John W. 2012. Educational research : planning, conducting, and evaluating quantitative and qualitative research - 4th ed. University of Nebraska-Lincoln.

Diane Larse-Freeman, Techniques and Principles in Language teaching, (Oxford University Press, 2000) pp. 113-114

Deli, E, (2019), The Implementation of BEDSRA Teaching Strategies in Teaching Reading Comprehhension at The Second Grade Students of SMP N 2 Jambi, English Education Study Program, Faculty of Teacher Training and Education. University of Batanghari Jambi.

Durkin, D. (1993). Teaching them to read (6th Ed.). Boston: Allyn \& Bacon

Fauziati Endang et al.2013.English Learning Teaching And Learning: Theory and practice. Modul PLPG (handbook).

Field, A. P. (2005). Discovering Statistics Using SPSS, Sage Publications Inc.

Grabe,W., \& Stoller, L. (2013). Teaching and researching Reading(2thedition). London and New York: Routledge.

Gerot, L., \& Wignell, P. (1995). Making Sense of Functional Grammar. NSW: Antipodean Educational Enterprise.

Gerot, L. and Wignell,P. 1994. Making Sense of Functiona; Grammar. Australia:

Gay, L. R. (2012) Educational research : competencies for analysis and applications/L.R. Gay, Geoffrey E. Mills; Peter Airasian.-10th ed, P.135.

Harmer, J. (2001). The Practice of English Language Teaching(3rdedition).Cambridge: Longman.

Harmer, J. (2001). The practice of English language teaching (3rd ed.). London, England: Pearson.

Jack C. Richards and Theodore S.Rodgers. Approaches and Methods in Language Teaching, (New York: Cambridge University Press, 1999),p.142

Kligner, Jannete K. 2007. Teaching Reading Comprehension to Students With Learning Difficulties. London: The Guilford Press.

Kothari, C. R. (2004). Research Methodology methods and techniques (2rd ed). Former Principal, College of Commerce University of Rajasthan, Jaipur India,p.35

Lozanov, G. (1982). Suggestology and suggestopedia. In R.E. Blair (Ed.), Innovative approaches to language teaching. Rowley, MA: Newbury House.

Lozanov, G. 2005. Suggestopaedia -Desuggestive Teaching Communicative Method On The Level Of The Hidden Reserves Of The Human Mind. B. Dimovsky Symbolic figures by G. Lozanov.

McMillan, James. H. (1996). Educational Research: fundamentals for the consumer (2rd ed). Virginia Commonwealth University,p.85.

Suyadi, (2020). The Effect of BEDSRA Teaching Strategies in Reading Comprehension at the 
Second Grade Students of SMP N 2 Kota Jambi in Academic Year 2018-2019. JELT: Journal of English Language Teaching, 2020

Venkanna, K., \&Glorry, N. (2015). " Use of suggestopedia as an innovative strategy for promoting effective reading comprehension abilities in English at the ESL level " An experimental study. International Journal of English Language, Literature and Humanities, 3(8), 128-149.

Wolly, G. (2011).Reading comprehension: Assisting children with learning difficulties. Brisbane: Springer. 